Open Access

\title{
Revisiting the 'ethnic enclave economy': resilient adaptation of small businesses in times of crisis in Spain
}

\author{
Hugo Valenzuela-Garcia ${ }^{*}$, Sònia Parella² and Berta Güell ${ }^{2}$
}

\author{
* Correspondence: \\ hugo.valenzuela@uab.cat \\ ${ }^{1}$ Egolab/GRAFO Research Group. \\ Department of Social Anthropology, \\ (UAB), Barcelona, Spain \\ Full list of author information is \\ available at the end of the article
}

\begin{abstract}
The term 'ethnic enclave economy', defined as a special case of ethnic economy, was formulated more than 25 years ago and since then has been subject to a great debate. Spatially concentrated businesses have for a long time been viewed as particularly anomalous and their economic significance for the society has been overlooked. Yet, recent processes of economic globalisation have generated growing demands for small and flexible businesses in urban cities, with the effect of an increasing number of ethnic entrepreneurial activities. This paper revisits the mainstream definitions of 'ethnic enclave', by taking into account new approaches that can be used to adapt the term to the dynamics of global economy and to disassociate it from a territorially fixed and circumscribed place. At the same time, these approaches provide a strong foundation to shape the enclave as a form of economic resilience in times of crisis. Most of the defining characteristics of the enclave explain how businesses are able to adapt and expand taking advantage of their competitiveness in spite of the economic recession. Such a line of argument is illustrated and discussed through empirical data from two case studies: Pakistani businesses in the neighborhood of Raval (Barcelona), and the Indian souvenir business in the Catalan coast (Girona).
\end{abstract}

Keywords: Migrant entrepreneurship, Ethnic economy, Globalisation, Transnationalism, Resilience, Spain

\section{Background}

The field of ethnic entrepreneurship has focused on the study of those processes immigrants follow to become entrepreneurs. Social exclusion in the open labour market and the limited opportunities for upward social mobility, along with the motivation to be an entrepreneur, generating greater incomes and improving the socio-economic status, are some of the elements that define ways to entrepreneurship. At the same time, using shared resources within the ethnic community, as well as class resources imported from origin and spread out through transnational ties, are particular strategies which lead to the emergence of ethnic economies.

Ethnic economies include self-employed people, employers and workers who share the same ethnicity (Light 1972; Bonacich and Modell 1980; Light and Gold 2000). Various authors have debated around the different types of ethnic economies, according to issues such as ethnic ownership (versus ethnic control), sectorial

(c) The Author(s). 2017 Open Access This article is distributed under the terms of the Creative Commons Attribution 4.0 International License (http://creativecommons.org/licenses/by/4.0/), which permits unrestricted use, distribution, and reproduction in any medium, provided you give appropriate credit to the original author(s) and the source, provide a link to the Creative Commons license, and indicate if changes were made. 
specialisation, customer base, interaction with the ethnic market, spatial concentration, institutional integrity or interdependence between firms. Among these typologies, the 'ethnic enclave economy' stands out as a special case of ethnic economy (Kaplan and Li 2006), which has been fairly controversial since it was formulated 25 years ago with data from specific minorities (Portes and Shafer 2007). It thus, deserves a retrospective overview along with the latest theoretical developments from different schools. Although the economic consequences of living in such enclaves is still an unresolved issue, it is true that these businesses have for a long time been viewed as particularly anomalous and their economic significance for the society has been overlooked (Light and Gold 2000; Sassen 2001).

While most common discussions about globalisation have focused on multinational companies and large movements of working migrants, these processes have created growing demands for small businesses in urban cities to deliver some services and products at lower prices. As a result, the global restructuring of labour markets has forced changes at the local level, with the effect of an increasing number of selfemployed and immigrant or ethnic minority businesses (Strüder 2003). This deserves the adoption of a new perspective at all relevant aspects of ethnic economies through a different lens. This kind of flexible business activity seems more able to adapt its products and services to changing circumstances, so it spreads quickly and finds more easily new opportunities in times of crisis.

This paper re-examines the mainstream definitions of 'ethnic enclave', in order to adapt the defining characteristics of this entity to the present dynamics of global economy. Firstly, we consider new perspectives that disassociate the ethnic enclave economy from a territorially fixed and circumscribed place, by introducing the notions of 'social space' (Werbner 2001); 'transnational economic practices' (Landolt 2001); 'economic device' (Ma Mung 1992, 1996; Audebert 2007) and the 'deterritorialised mobility competences' that characterize the 'bazaar economy' (Péraldi, Foughali and Spinosa 1999; Peraldi 2005). These various approaches allow to shape the enclave as a form of economic resilience (Valenzuela 2013). Secondly, we highlight two case studies which display the resilient character of enclaves and discuss how they are related to such theoretical nuances. They are both based in Spain: on the one hand, Pakistani businesses located at the neighbourhood of Raval at the heart of Barcelona, and on the other, the Indian souvenir businesses in the Catalan Coast.

\section{Methods}

This paper offers a review of the mainstream literature on ethnic enclaves and migrant economy and discusses the relevance of this literature in the case of two ethnic enclaves located in Catalonia: an ethnic Pakistani enclave in the center of the city of Barcelona; and an Indian enclave located in the town of Lloret de Mar (in the Catalan Costa Brava). While some of the data belongs to a research study undertaken within the PhD around Pakistani businesses in Barcelona (Güell 2012), in both enclaves we have applied a similar mixed methodology (qualitative-quantitative). On the one hand, extensive ethnographic fieldwork has been carried out (two years in one case and three in the other, by members of two research teams of anthropologists and sociologists) accompanied by participant observation, questionnaires and semi-structured interviews. On the other hand, official population statistics sources and censuses on the economic 
activity of these commercial clusters (town halls and chambers of commerce) and, in some cases, social network analysis have been used.

\section{Theoretical Overview of the 'Ethnic Enclave Economy}

The academic interest in the emergence of ethnic economies controlled by immigrants and ethnic minorities was born in the U.S.A. in the 1970s, due to the increase of small entrepreneurs among the migrant population, and has later on spread throughout Europe (Light 1972, Body-Gendrot and Ma Mung 1992; Light and Rosenstein 1995; Portes and Stepick 1993; Waldinger 1996; Rath and Kloosterman 2000). Beyond the more generic term of 'ethnic economy', there are different ways in which certain ethnic groups engage in the entrepreneurial activity (Barret et al., 2001; Light and Gold 2000; Kaplan and Li 2006).

The term 'ethnic enclave economy' is a special case within the general framework of ethnic economy (Zhou 2004; Kaplan and Li 2006). Wilson and Portes (1980), on the basis of data from Cuban exiles who arrived in the United States in the early 1970s, identified ethnic enclaves as a distinct form of economic adaptation. These formations were characterised by the spatial concentration of immigrants, by a substantial proportion of workers of the same nationality employed in these firms and by the variety of manufacturing and commercial sectors.

Portes and Bach (1985) claimed that the enclave was a distinct economic sector, different from the "primary" and "secondary" sectors of the labour market. Those in the enclave had economic benefits that corresponded more closely with their educational attainment, compared to immigrants employed in the mainstream economy -mainly in the secondary sector. In this sense, by definition, the ethnic enclave constitutes a different form of economic adaptation (Wilson and Portes 1980). It emerges essentially to cope with the limiting access to the mainstream labour market which tends to segregate ethnic minorities (Qadeer and Kumar 2006:3).

The enclave offers a protected environment with privileged access to employment, labour force (Wilson and Portes 1980), information, loans (Light 1972; Bonacich and Modell 1980), experience or capital (Portes and Zhou 1992), based on relationships of trust and ethnic solidarity. These resources involve an almost monopolistic advantage in competitive contexts (Light and Gold 2000) and are mobilised through social networks, the base of social and relational capital. Within networks different relationships can be distinguished: a) strong ties among family and close friends, which are crucial in providing funding, b) weak ties: casual friends and colleagues which are advantageous for circulating information (Granovetter 1973), c) horizontal links which limit the economic activity in a few sectors, causing a specialisation that can be transmitted to the group (e.g. Chinese restaurants, Jewish garment industry, kebabs, etc.), d) downward vertical links which promote dependency between various co-ethnic producers and suppliers (outsourcing of co-ethnics), and e) upward vertical links which enable the relationship between producers and customers (i.e., stimulation of specific niches such as food).

In the scholarly literature there has been a long debate regarding the 'ethnic enclave economy' hypothesis. According to it, clustering should benefit both, ethnic enterprises and their workers. There are explanations that highlight its competitive advantages arguing that the enclave can be a "mobility machine" and at the same time reproduces some of the features that account for successful firms in the wider economy 
(Light 1972; Jiobu 1988; Portes and Jensen 1987, 1989; Wilson and Portes 1980). In contrast, other researchers have displayed their scepticism about the beneficial effects of being employed in an immigrant firm (Borjas 1986; Sanders and Nee 1987; Waldinger, Aldrich, and Ward 1990; Bailey and Waldinger 1991; Waldinger 1993; Yuengert 1995; Ahmad 2010). Yet, if we think of the ethnic enclave as a social system with structures that reproduce internal inequalities, it is possible to include both approaches (Valenzuela 2013).

More recently, scholars have focused on the spatial concentration feature and on the social processes connected to the economic globalisation in which small businesses and ethnic economies in particular- have new advantages (Light 2011). Certainly, in the past, ethnic enclaves gathered businesses in immigrant neighbourhoods with a high presence of co-ethnic residents being also intertwined in an intricate system of coethnic social networks within a self-sustaining structure (Zhou 2004). However currently a series of processes having to do with the globalisation of the economic activity and the increasingly marked racialisation of labour market segmentation place the ethnic economy at the core of urban economies, because of the exceptional involvement of transmigrants in international trade (Sassen 2005; Light 2011).

Werbner (2001) rejects the notion of the ethnic enclave economy as a territorially circumscribed place, and affirms that ethnic businesses are embedded in inter-firm relations that produce social space by trading particular goods and commodities in nodal points, which are vertically and horizontally organised. Other approaches make interesting contributions to the link between transnationalism, entrepreneurship and immigrant settlements (Portes 2003; Portes and DeWind 2004). Portes, Guarnizo and Haller (2002) ${ }^{1}$ examine the prevalence of transnational entrepreneurship in immigrant communities and introduce the concept of 'transnational social space' in order to capture the dynamics of some ethnic businesses. Landolt (2001) examines a case study of the transnational economic practices linking two Salvadoran settlements in the USA and El Salvador. By theorising the nature of transnational entrepreneurship among Salvadorians, she argues that "it extends beyond the migrant population and envelopes the El Salvador's entire business landscape” (2001:236).

From a transnational perspective, Stefoni (2013) shows how the significant concentration of commercial activities and everyday practices of Latin American immigrants in the emblematic 'Plaza de Armas' in the centre of Santiago de Chile has led to the creation of a 'transnational ethnic enclave'. In Europe, for the case of Berlin, Miera (2008) explains the early orientation towards an open and transnational market among Polish entrepreneurs in comparison to the more local orientation of prior Turkish entrepreneurship. Strategies of Polish entrepreneurs highlight the relevance of transnational social networks and mobility in the context of national and transnational market conditions and politico-institutional frameworks.

Although in France there are less studies focused on the growing presence of international migrants in independent economic activities (compared to English-speaking countries), notorious scholars, mainly from the geography discipline, have introduced dynamic conceptualisations to immigrant entrepreneurship that must be taken into consideration. Unlike the idea of 'enclave' as encapsulated and with a fixed structure, they focus on devices characterised by flexibility and a constant internal reorientation (Ma Mung 1992, 1996; Péraldi, Foughali and Spinosa 1999; Audebert 2007). It involves 
an attempt to highlight the evolutionary and circumstantial -non-permanent, even short-term features of the economic arrangements among different actors, all of them qualified as 'ethnic'. This approach also reconsiders the placement of the immigrant business in the space just as a possible consequence of these arrangements, by introducing the concepts of 'deterritorialisation' and 'transnationalism'. From this perspective, immigrant entrepreneurs are embedded in local and transnational strategies at the same time, within a vulnerable social and economic frame which is both local and transnational (Audebert 2007).

The term 'economic device' (dispositif économique), introduced by Ma Mung (1992, 1996), revisits the 'enclave debate' by underlining the agency of migrants and the prevalence of ethnic considerations in the choice of economic partners. This concept highlights the dynamic dimension of ethnic economies and it pays particular attention to the mechanism of decision-taking used by entrepreneurs in the process of partner's choice, which is not essentialist or substantialist, but always connected to a specific context. Ma Mung (1992) describes how the Chinese Diaspora is structured around an entrepreneurial centre, with activities "strongly connected" to an "economic organisation in which the dimension of identity is predominant" (1992:117), and with a spatial layout of the businesses, mainly in the region of Paris.

By thinking of the circumstantial nature of the economic arrangements within "economic devices", Péraldi (2005) shows a different way to choose economic partners based on an ethnic consideration too, looking specifically at Marseille (France). He describes how new forms of migration and mobility from the South to the North are appearing in marketplaces of northern Mediterranean cities like Istanbul or Marseille, where the figure of migrant worker has been replaced by "the commercial traveller, the smuggler or the long-distance trader" (2005:47). These transborder commercial activities involve the development of pluri-ethnic, pluri-cultural and pluri-religious networks (Turkish, Maghrebi and African immigrants) in order to make the economic transactions possible. These are based on future reciprocal commitment and the importance attached to reputation and the code of honour (Missaoui 1995).

This pattern is conceptualised as 'bazaar economy' (Geertz 1978), a social institution that exists in all European cities, but is consolidated in big commercial border towns like Marseille. Péraldi, Foughali and Spinosa (1999) identify three main distinctive features of the 'bazaar economy'. First, the social and urban devices of the bazaar are determined by long-term face-to-face relationships (for instance, a broad network of credit relationships) rather than by formal contracts and normative institutional arrangements. Second, there is an articulation local/global sustained by the 'competence in mobility' (compétences à mobilité) of transnational migrants, which solves the paradox of physical dispersion and the prevalence of links that promote relationships, communication networks and other resources to facilitate more effective participation in the 'bazaar economy'. Third, economic benefits are determined by the capacity of actors to develop strategies and mechanisms to cross frontiers restricted to formal crossing and to offer certain products on the market, both licit or illicit, thanks to the North-South commercial routes.

In Spain, some authors deny the existence of ethnic enclaves due to the relative short time of settlement, the limited scope of ethnic entrepreneurial communities, the difficulty of applying the theoretical model to the case of Spain, and to the legal and 
administrative barriers that prevent the consolidation of these economies as enclaves (Arjona and Checa 2006; Solé and Parella 2005). Torres (2007), on the basis of Ma Mung's approach, rejects the use of the term 'ethnic enclave' to capture the spatial concentration of immigrant businesses in the neighbourhood of Russafa (València, Spain). He recalls the concept of 'centrality of immigrant commerce' (centralité marchande immigrée), where spatially concentrated businesses do not necessarily present economic relationships between them. Yet, they may be related to other commercial activities belonging to the same family group or to other co-ethnics or providers with businesses in other cities. 'Russafa' is described like a 'link', i.e. just as a physical space where people meet each other and look for information and informal resources.

\section{The enclave as a resilient entity}

'Resilience' is an increasingly used concept within the academia to highlight the ability of human beings to adapt to and overcome adversities, especially at times of crisis. As the etymological origin recalls, resilience means to 'bounce', from the latin resilio or resilire. It was first rooted in the field of ecology related to the discovery of multiple basins of attraction in ecosystems in the 1960-1970s, and it later inspired social and environmental scientists to challenge the dominant stable equilibrium view (Folke 2006).

The enclave, seen as a socio-ecological system, allows to be approached from the resilience point of view. However, in the case of the ethnic enclave, resilience should be understood as a unitary entity rather than individual companies and businesses constituting the enclave. Paradoxically, although the rate of replacement, closure and transfer of businesses is high within the enclave (due to strong internal competition and economic vulnerability), the whole of the enclave is able to adapt and expand in spite of the economic crisis. Based on our case studies we suggest several explanations for the resilient character of the ethnic enclaves.

While there may be diversity of contexts and socioeconomic structures within the ethnic economy, we believe that the enclave's resilience derives from several elements, such as the use of specific (ethnic and class) resources; the ability to navigate between the formal and informal sectors; the capacity to exploit the labour factor; the spatial concentration; and the transnational social field in which ethnic entrepreneurs are potentially connected. Inside the enclave, dense social networks generate one of its main competitive advantages through which different types of capital and resources flow (labour force, information, mutual support, informal credit, etc.) (Model 1985).

Because immigrants tend to occupy secondary market workplaces not covered by native workers (Solé, Parella and Alarcón 2009), their economic initiatives tend to be convenience stores (small corner shops) run by acquaintances as the model of family businesses. This allows high levels of labour exploitation and flexibility -in terms of working hours, schedules, etc. The process of recruitment, the administrative status of workers (e.g. often undocumented), the existence of a large pool of co-ethnic workers and the lack of specific human capital as a requirement to work in these shops make labour an abundant and cheap resource.

As previously mentioned, ethnic economies tend to move on the edge of the informal economy (Yuengert, 1995), which provides them with some advantages over formal businesses in terms of access to employment, business practices, or taxation. This 
tendency allows the emergence of 'bazaar economies' (Geertz 1978, Péraldi, Foughali and Spinosa 1999), a practice usually imported from the countries of origin depending largely of the control of information available, customer loyalty and bargaining.

As in the Marshalian industrial districts (Markusen 1996), spatial concentration limits transaction costs and facilitates access to resources (e.g. capital, information, work), and to customers and distributors (Wilson and Portes 1980; Portes and Bach 1985) (Kaplan 1997: 215). In other words, spatial concentration favours both vertical and horizontal integration and confines the expenses of trade activity. The settlement in urban and multicultural spaces provides a constant flow of customers (e.g. tourists), perhaps less reluctant than native people to buy at those stores. Enclave competitiveness also derives in expanding its boundaries beyond the limits of the ethnic community and in approaching non-marginal generalist niches. Finally, another factor of resilience relates to the presence of a latent transnational social field (Levitt and Glick-Schiller, 2004) which, regardless of the available local resources, might provide further economic possibilities for co-ethnic workers and employers to struggle against the odds.

\section{Results: two case studies of ethnic economies in Spain}

Starting from the previous theoretical framework, we will discuss the notions of resilience and ethnic enclave applied to the analysis of two Asian ethnic enclaves located in Catalonia: a Pakistani enclave located in the context of the old quarter of Barcelona and an Indian enclave found in the town of Lloret de Mar, on the Catalan coast.

According to the last official population census (INE 2013) there are 80,714 Pakistanis in Spain, of which 59\% live in Catalonia (autonomous community in Spain) and one fourth (27\%) in Barcelona. Within the city, they are greatly concentrated in the multicultural neighbourhood of Raval (26\%), which is located in the old town, and today sum up the second largest foreign group after the Italians (of whom many are Latin Americans with double citizenship). This is where the successive waves of immigrants have settled from the late 1970s thanks to the presence of key centres of socialisation such as businesses, associations and mosques (Beltrán and Sáiz 2007). This kind of immigration has evolved through chains of immigration in successive waves, usually as a decision taken by the whole family from a strategic and rational point of view by analysing the costs and benefits of the migration project (Feixas 2009).

Unlike other migratory groups (e.g. Romanians, Moroccan, Dominicans), Pakistanis do show an atypical space concentration of both residence and economic activities in this particular neighbourhood. Just during the last years, and probably by an effect of space saturation and upward mobility, Pakistanis have also tended to establish their residences and businesses in other areas of the city (e.g. Besòs, Sants or Ciutat Meridiana). Raval has become a lively destination for subsequent Pakistani newcomers bringing up a local commercial revitalisation of the area, as well as cultural and political engagement through associations, Urdu media and religious centres, ${ }^{2}$ all of them key spaces of socialisation (Beltrán and Sáiz 2007; Werbner 2001; Aldrich 1975).

Residential concentration has thus facilitated the emergence and growth of an ethnic economy which displays characteristics of the enclave despite the increasing spread over the city as a result of the crisis. Taking the example of Raval as the diasporic node of the community, this neighbourhood today gathers around 250 small, family-based, businesses run by Pakistanis. They tend to cluster in specific niches such as phone 
shops, Internet points and call centres (locutorios), and supermarkets. This is a common element within enclaves, as they make use of the vertical and horizontal integration by sharing contacts within the chains of production and supply (Werbner 1990, 2001). Yet, in the face of the multiplication of businesses, ${ }^{3}$ there are also logics of competition and entrepreneurs try to start-up in other kind of shops aiming at differentiation. Some examples include restaurants and fast-food stores (döner, kebab, etc.), hairdressers, halal butcheries, groceries, bakeries, travel agencies, as well as other minor businesses such as, tailors, bazaars, jewelleries, electrical appliances shops, bars or laundries. Business turnover involving a change in the title of the business property between Pakistanis is quite common. This strategy requires that information circulates easily within ethnic and social networks.

Ease of access to material and non-material resources (e.g. information, cheap coethnic workforce, funding) allows even those migrants with fewer resources to become entrepreneurs. The strategic location just in the heart of the inner city has assured them access to a wider and diverse clientele: co-ethnics, local and tourists alike. The tendency towards 'open market' businesses is also assessed as a mechanism to encompass a wider customer base, the broader society, rather than promoting solely 'products oriented to a more local 'ethnic community'. Summing up, there are different elements which are activated as resilience strategies to adapt at times of crisis: access to and use of ethnic and class resources; sectorial specialisation with disregard of a parallel diversification; share of social capital through networks and engagement in community associations.

Lloret de Mar is a very popular seashore village located on the coast of Gerona, Catalonia. During the 1970s tourism development caused a dramatic population growth triggered by both Europeans who established their second residence in Lloret and migrant and Spanish workers in search of better economic prospects. Today's population comprises 40,000 inhabitants: Spanish (57\%), EU residents (17.5\%), Latin-Americans (6.2\%), Africans (5\%), Asians (5\%) and others. Amongst these newcomers the presence of Sindh and Punjabi Indians is especially noticeable. During the last two decades they have quickly settled and scattered their businesses across the town and today there are at least 150 businesses run by Indians. Their community includes 1266 people according to the Official Census and they are mostly male, young and unskilled. They represent almost $4 \%$ of the foreign dwellers living in Lloret de Mar, a noticeable percentage compared to the $0.07 \%$ found in Spain (Idescat 2012). In the absence of relevant historical, sociocultural or political bilateral contacts between both countries, their presence in the country should be attributed to the Indian Diaspora (Vertovec 2000), as it happens with Pakistanis.

Although early Indian communities first settled in Gibraltar, Andorra or the Canary Islands (López Sala 2007), the community in Lloret arrived from Andorra and Barcelona (particularly after the Olympic Games of Barcelona in 1992) and spread along the north-western coastal corridor, establishing their businesses across popular tourist spots such as Calella, Benidorm, Blanes, Salou and Lloret de Mar. They were followed by other countrymen who joined as employees and some of them eventually became entrepreneurs themselves. The new Indian entrepreneurship quickly displaced local (Catalan) and other (mostly Pakistani and Moroccans) competitors alike.

What is remarkable in this case is the overwhelming presence of Indian workers and entrepreneurs in the tourist sector, comprising Indian restaurants and fast-food chains 
(Tandoori restaurants, Döner kebabs, etc.), hair-dressers, liquor stores, shoe shops and, above all, souvenir shops. The souvenir retail sector involves at least $80 \%$ of the Indian manpower. A representative sample of 60 stores from the main commercial spots showed that the souvenir retail shops involve 40\% (24) of the stores, and Indians manage $92 \%$ of these, while local shopkeepers just run two in this area. Restaurants, bars, fast-food outlets and other food shops comprise 32\% (19) of the sample: $10 \%$ of these are managed by Indians and the rest (13) are run by local Catalans, British, Germans, Dutch or Latin-Americans. Most liquor stores are also run by Indians.

Throughout the exploitation of the souvenir niche, Indian businesses are coping quite well with the economic crisis. The unusual concentration of Indians both in an economic sector and in a given geographical area recalls the theoretical concept of 'ethnic enclave' (Portes and Manning 1986; Morris 2000, Valenzuela et al. 2013), understood as a socio-economic and cultural complex that provides economic advantages to a certain population in a specific location. As it is highlighted in the theory, the enclave strategy overcomes the barriers to access mainstream labour market -being one of the most relevant paths to attain social integration- and to play indeed a relevant societal role in terms of socio-cultural cohesion, economic performance, and urban regeneration. Indians involved in the souvenir sector point out how within such a socioeconomic structure, solidarity articulates several forms of capitals based on a common shared ethnic identity: social capital (e.g. informal credit systems), relational capital (e.g. contacts, information, social networking), and human capital (job opportunities, informal education or entrepreneurial training). This case shows how the enclave also reduces labour costs, increases competitiveness, and provides loyal employers, since labour recruitment is carried out through personal networks and references.

\section{Conclusions}

The theoretical revision of ethnic economies and particularly of the 'ethnic enclave economy' points out how this was initially framed as a fixed category where immigrant businesses operated within the dynamics of circumscribed places (e.g. Little Havana in Miami). This was in large part thanks to the spatial concentration, the development of an institutional completeness which runs parallel to the mainstream institutions, and to the use of resources which stemmed from co-ethnic residents or entrepreneurs.

Today, the global economy has affected the way we understand economic and social relationships. As a result, the concept of 'ethnic enclave' needs to be revisited making use of the latest theoretical developments which disassociate this kind of ethnic economy from a territorially limited area. This is by including the notion of 'social production of space, where the capital and resources circulate through social networks which go beyond the physical space. It is precisely the share of contacts of providers and suppliers and the specialisation in a certain sector (what Werbner calls vertical and horizontal integration) what enables the persistence and consolidation of an enclave even if this is constituted by businesses placed in different neighbourhoods or cities.

The transnational paradigm also poses interesting challenges to the notion of enclave, as it considers the interaction of communities between different nodal points established in various countries (multi-local), although there is often a greater degree of connection between the 'place of origin' and the 'place of destination'. Finally, the concepts of 'economic device' (Ma Mung 1992, 1996; Audebert 2007) and 'bazaar 
economy' (Péraldi, Foughali and Spinosa 1999; Péraldi 2005) in frontier spaces, such as the city of Marseille, suggest that economic activity takes place in a dynamic way, where the transnational and local dimensions meet together in a common place. Also, migrants seem to place much importance to the identity as a criterion to establish a business in terms of relationships with employers and clients and this process can be shaped in itinerary places, as represented in the figure of 'commercial traveller' or 'long-distance trader'. In this sense, the abilities to start-up and manage a business are subject to mobility and are learnt and transmitted on an informal basis through interactions in meeting points.

Yet, these various forms of approaching ethnic economies have in common the resilient character to adapt in adverse contexts. This is characterised by the blockage, discrimination or segregation from the open labour market, or other structural processes such as the current crisis. Actually, as the original concept recalls, the ethnic enclave is a different form of economic adaptation (Wilson and Portes 1980) which emerges to overcome hindrances in access to the mainstream labour market (Qadeer and Kumar 2006). The fact that ethnic economies expand at times of crisis (Werbner 1990) is also a clear element of resilience. The greater facilities to access resources such as flexible and economic workforce, the navigation between the informal sector and formal economy or the potential transnational social field may constitute an advantage over autochthonous entrepreneurs and help in starting-up and managing a business.

The resilient attribute of ethnic economies has been displayed in both case studies here presented. Güell (2012) proves how Pakistani businesses in the neighbourhood of Raval in Barcelona have doubled from 2001 to 2011, a great part of which has a life not older than 2 years. The strategies to open a business at times of crisis are determined by the facility to achieve ethnic and class resources, both material and not material, as well as the ability to articulate several forms of capital based on a shared ethnic identity (Güell 2016). The same pattern is observed in the case of the business sector controlled by Indians in the Catalan coast. The dominance of this particular niche provides a competitive advantage over local entrepreneurs to achieve and sell all kind of products at lower prices.

In Spain there is not a consensus on the existence of ethnic enclave economies. This is in part due to the disagreement with the 'traditional' concept of ethnic enclave understood as a fixed category focused on spatial concentration. Yet, it is important to consider the aforementioned theoretical nuances to examine how the economic activity of migrants around businesses is constructed and transformed over time. In this sense, if the enclave is considered as a socially produced space, which may incorporate potential transnational practices combined with local dynamics in mobile and deterritorialised scenarios, we may be able to identify further empirical cases with a revisited concept of 'ethnic enclave economy'.

\section{Endnotes}

${ }^{1}$ The CIEP survey of over 1200 Colombian, Dominican, and Salvadoran family heads is the first to explicitly measure the extent of economic, political, and socio-cultural transnationalism among immigrants and to develop predictive models of these activities. The study was designed to examine the prevalence of transnational entrepreneurship in immigrant communities and to provide basic information about its empirical contours and correlates. 
${ }^{2}$ Most Pakistani are Sunni Muslim and only in Raval there are 6 mosques (Moreras 2005).

${ }^{3}$ This is highlighted by the fact that almost half of the sample has a life of between 1 and 3 years showing both a high level of "economic mortality" and a clear pattern of commercial growth.

\section{Acknowledgements}

We thank Dr. Jose Luis Molina for a previous review of the paper and we would like to thank both the Pakistani and Indian communities for their cooperation in the research process.

\section{Funding}

Funding sources include the next projects: (1) 'Profiles of Ethnic Entrepreneurship (2010-2012); 'Perfiles del Empresariado Étnico en España', MICINN (CSO2009-07057, 2010-2012); (2) ORBITS. The Role of Social Transnational Fields in the Emergence, Maintenance and Decay of Ethnic and Demographic Enclaves. MINECO-FEDER (CSO2015-68687-P; 2016-2020); (3) 'Los negocios étnicos en España', DGICYT (SEC2003-0016213 2004-2006).

\section{Availability of data and materials}

Data collected and material are stored and available at Nebula repository, Universitat Autònoma de Barcelona.

\section{Authors' contributions}

All three authors have contributed equally to the manuscript in terms of data sources, data analysis, discussion, and writing. HV provided the ethnographic data in the case of the Indian enclave, wrote the first part of the paper and leaded the final process of the writing. BG provided the ethnographic data of the Pakistani case and wrote several sections of the paper. SP developed the part concerning the French scholars and reviewed the theoretical paper. All authors read and approved the final manuscript.

\section{Competing interests}

We declare that we have no competing interests.

\section{Publisher's Note}

Springer Nature remains neutral with regard to jurisdictional claims in published maps and institutional affiliations.

\section{Author details}

${ }^{1}$ Egolab/GRAFO Research Group. Department of Social Anthropology, (UAB), Barcelona, Spain. ${ }^{2}$ GEDIME/CER-Migracions Research Group. Department Sociology, Universitat Autònoma de Barcelona, Barcelona, Spain.

Received: 10 August 2017 Accepted: 8 November 2017

Published online: 18 December 2017

\section{References}

Ahmad, Ali. 2010. Pakistaníes en Italia. Revista CIDOB d'Afers Internacionals 92: 161-183.

Aldrich, Howard. 1975. Ecological succession in racially changing neighborhoods: A review of the literature. Urban Affairs Quarterly 10 (3): 327-348.

Arjona, Ángeles, and Juan Carlos Checa. 2006. Economía étnica. Teorías, conceptos y nuevos avances. Revista Internacional de Sociología 45: 117-143.

Audebert, Cédric. 2007. Introduction. Penser l'entreprenariat etnique. De nouvelles orientations sicentifiques pour des enjeux sociétaux réactualisés. In Les nouveaux territoires migratoires : entre logiques globales et dynamiques locales, ed. Cédric Audebert and Emmanuel Ma Mung, 81-86. Bilbao: Université de Deusto/ HumanitarianNet.

Bailey, Thomas, and Roger Waldinger. 1991. Primary, secondary and enclave labor markets: A training systems approach. American Sociological Review 56 (4): 432-445.

Barret, Giles, Trevor Jones, and David McEvoy. 2001. Socio-economic and policy dimensions of the mixed embeddedness of ethnic minority business in Britain. Journal of Ethnic and Migration Studies 27 (2): 241-258.

Beltrán, Joaquín, and Amelia Sáiz. 2007. La comunidad pakistaní en España. In Anuari Asia Pacífic 2007, 407-416. Barcelona/Madrid: Casa Àsia, Fundació Cidob and Real Instituto Elcano.

Body-Gendrot, Sophie and Ma Mung, Emmanuel. 1992. Entrepreneurs entre deux mondes : les créations d'entreprises par les étrangers : France, Europe, Amérique du Nord (coordination of monographic issue) Revue européenne des migrations internationales 8 (1): 205.

Bonacich, Edna, and John Modell. 1980. The economic basis of ethnic solidarity: Small business in the Japanese American community. Berkeley: University of California Press.

Borjas, George J. 1986. The self-employment experience of immigrants. Journal of Human Resources 21: 485-506.

Feixas, Montserrat. 2009. Testing migration hypothesis: The movement of people from Pakistan to Catalonia. New Issues in Refugee Research 170: 1-11.

Folke, Carl. 2006. Resilience: The emergence of a perspective for social-ecological systems analyses. Global Environmental Change 16 (3): 253-267.

Granovetter, Mark. 1973. The strength of weak ties. The American Journal of Sociology 78 (6): 1360-1380.

Geertz, Clifford. 1978. The Bazaar Economy: Information and Searchin Peasant Marketing. American Economic Review 68:28-32. 
Güell, Berta. 2012. Els negocis dels pakistanesos al barri del Raval a Barcelona. Motius i estratègies per a l'autoocupació. MA Thesis dissertation. University of Barcelona. Barcelona. 167 pages.

Güell, Berta. 2016. The Backstage of Pakistani Businesses in Barcelona: Unravelling Strategies from the Ground. South Asian Diaspora Journal, 8 (1): 15-30.

Idescat. 2012. Instituto De Estadística de Cataluña. http://www.idescat.cat/es/. (Accessed on 20 th June 2012).

INE. 2013. Instituto Nacional de Estadística. http://www.ine.es/. (Accessed on 4th July 2014).

Jiobu, Robert. 1988. Ethnic hegemony and the Japanese of California. American Sociological Review 53: 353-367.

Kaplan, David H. 1997. The creation of ethnic economy: Indochinese business expansion in Saint Paul. Economic Geography 73 (2): 214-233.

Kaplan, David H., and Wei Li. 2006. Landscapes of the ethnic economy. New York: Rowman \& Littlefield Publishers.

Landolt, Patricia. 2001. Salvadoran economic Transnationalism: Embedded strategies for household maintenance, immigrant incorporation and entrepreneurial expansions. Global Networks 1: 217-242.

Levitt, Peggy, and Nina Glick-Schiller. 2004. Conceptualizing simultaneity: A transnational social field perspective on society. International Migration Review 38 (3): 1002-1039.

Light, Ivan. 1972. Ethnic Enterprise in America: Business and welfare among Chinese, Japanese, and blacks. Berkeley: University of California Press.

Light, Ivan. 2011. Global entrepreneurship and transnationalism. In World Encyclopedia of Entrepreneurship, ed. Léo-Paul Dana. London: Edward Elgar Publishing.

Light, Ivan, and Steven J. Gold. 2000. Ethnic economies. San Diego: Academic Press.

Light, Ivan, and Carolyn Rosenstein. 1995. Race, ethnicity and entrepreneurship in urban America. New York: Aldine de Gruyter.

Mamung, Emmanuel. 1996. Entreprise économique et appartenance ethnique. Revue Européenne des Migrations Internationales 12 (2): 211-233.

Markusen, Ann. 1996. Sticky places in slippery space: A typology of industrial districts. Economic Geography 72 (3): $293-313$.

Miera, Frauke. 2008. Transnational strategies of polish migrant entrepreneurs in trade and small business in Berlin. Journal of Ethnic and Migration Studies 34 (5): 753-770.

Missaoui, Lamia. 1995. Petit ici, Notables là-bas. Revue Européenne des Migrations Internationales 11 (1): 53-75.

Model, Suzanne. 1985. Comparative perspective on the ethnic enclave: Blacks, Italians, and Jews in new York City. International Migration Review 19 (1): 64-81.

Morris, H. 2000. The power of ethnic entrepreneurship. Journal of Development Entrepreneurship 5 (2): 5-7.

Moreras, Jordi. 2005. ¿Ravalistán? Islam y configuración comunitaria entre los paquistaníes en Barcelona. Revista CIDOB D’Afers Internacionals, 68: 119-132.

Mung, Emmanuel Ma. 1992. Dispositif economique et ressources spatiales: elements d'une economic de diáspora. Revue Europeenne des Migrations Internationales 8 (3): 175-193.

Nee, Victor, and Jimy Sanders. 1987. On testing the. Enclave-economy hypothesis. American Sociological Review 52: 771-773.

Péraldi, Michel. 2005. Algerian routes: Emancipation, Deterritorialisation and Transnationalism through suitcase trade. History and Anthropology 16 (1): 47-61.

Péraldi, Michel, Nouara Foughali, and Nancy Spinosa. 1999. Le marché des pauvres, espace commercial et espace public. Revue européenne de migrations internationales 11 (1): 77-97.

Portes, Alejandro. 2003. Theoretical Convergencies and empirical evidence in the study of immigrant Transnationalism. International Migration Review 37: 814-892.

Portes, Alejandro, and Robert Bach. 1985. Latin journey: Cuban and Mexican immigrants in the United States. Berkeley: University of California Press.

Portes, Alejandro, and Josh DeWind. 2004. A cross-Atlantic dialogue: The progress of research and theory in the study of international migration. International Migration Review 38 (Fall): 828-851.

Portes, Alejandro, Luis E. Guarnizo, and William Haller. 2002. Transnational entrepreneurs: An alternative form of immigrant economic adaptation. American Sociological Review 67 (April): 278-298.

Portes, Alejandro, and Robert D. Manning. 1986. The immigrant enclave: Theory and empirical examples. In Competitive ethnic relations, ed. Susan Olzak and Joane, 47-68. Orlando (FI): Academic Press.

Portes, Alejandro, and Steven Shafer. 2007. Revisiting the enclave hypothesis: Miami twenty-five years later. The sociology of entrepreneurship. Research in the Sociology of Organizations 25: 175-190.

Portes, Alejandro, and Alez Stepick. 1993. City on the edge. In The transformation of Miami. Los Ángeles: University of California Press.

Portes, Alejandro, and Min Zhou. 1992. Gaining the upper hand: Economic mobility among immigrant and domestic minorities. Ethnic and Racial Studies 15 (October): 491-522.

Portes, Alejandro, and Leif Jensen. 1987. What's an. Ethnic enclave? The case for conceptual clarity. American Sociological Review 52: 768-771.

Portes, Alejandro, and Leif Jensen. 1989. The enclave and the entrants: Patterns of ethnic Enterprise in Miami before and after Mariel. American Sociological Review 54 (6): 929-949.

Qadeer, Mohammad, and Sandeep Kumar. 2006. Ethnic enclaves and social cohesion. Canadian Journal of Urban Research 15 (2): 1-17.

Rath, Jan, and Robert Kloosterman. 2000. Outsider's business. A critical review on immigrant Enterpreneurship. International Migration Review 34 (3): 656-680.

Sala, Ana María López. 2007. Migración internacional, vínculos transnacionales y economía étnica. El caso de la comunidad indostánica en Canarias. Revista CIDOB d'Afers Internacionals 78: 97-120.

Sassen, Saskia. 2001. The global city. Princeton (NJ): Princeton University Press.

Sassen, Saskia. 2005. Regulating Immigration in a Global Age: A New Policy Landscape. Parallax, volume 11(1): 35-45.

Solé, Calota, Sònia Parella, and Amado Alarcón. 2009. El autoempleo de las trabajadoras inmigradas. ¿Una alternativa a la discriminación laboral. Cuadernos de Relaciones Laborales 27 (1): 171-200.

Solé, Carlota, and Sònia Parella. 2005. Negocios étnicos. Los comercios de los inmigrantes no comunitarios en Cataluña. Barcelona: Fundació CIDOB. 
Stefoni, Carolina. 2013. Formación de un enclave transnacional en la ciudad de Santiago de Chile. Migraciones Internacionales 7: 161187.

Strüder, Inge R. 2003. Self-employed Turkish speaking women in London - Opportunities and constraints within and beyond the ethnic economy. International Journal of Innovation and Entrepreneurship 4 (3): 185-195.

Torres, Francisco. 2007. Les entreprises ethniques: économie, sociabilité et identité. Le cas du quartier de Russafa a Valènce (Espagne). In Les nouveaux territoires migratoires : entre logiques globales et dynamiques locales, ed. Cédric Audebert and Emmanuel Ma Mung, 97-110. Bilbao: Université de Deusto/HumanitarianNet.

Valenzuela-Garcia, Hugo. 2013. Guerra de sombrillas: enclave étnico indio, economía bazar y conflicto potencial en la costa catalana. In Retos y estrategias del empresario étnico contemporáneo. Estudios de caso de empresarios latinos en Estados Unidos y empresarios étnicos en España, ed. M. Barros Nock and H. Valenzuela, 47-68. México, DF: Ciesas.

Valenzuela-Garcia H., Molina, J. L., Lubbers, M. J., García-Macias, A., i Pampalona, J. 2014. On Heterogeneous and Homogeneous Networks in a Multilayered Reality: Clashing Interests in the Ethnic Enclave of Lloret de Mar. Societies 4: 85-104.

Vertovec, Steven. 2000. The Hindu diaspora: Comparative patterns. New York: Routledge.

Waldinger, Roger. 1993. The ethnic enclave debate revisited. International Journal of Urban and Regional Research 17: 444-452.

Waldinger, Roger. 1996. From Ellis Island to LAX: Immigrant Prospects in the American City. International Migration Review 30 (4): 1078-1086.

Waldinger, Roger, Howard Aldrich, and Robin Ward. 1990. Opportunities, group characteristics and strategies. In Roger Waldinger, Howard Aldrich, and Robin Ward, ed. Ethnic Entrepreneurs, 13-49. London: Sage Publications.

Werbner, Pnina. 1990. The migration process. Capital, gifts and offerings among British Pakistanis. New York: Berg.

Werbner, Pnina. 2001. Metaphors of spatiality and networks in the Plural City: A critique of the ethnic enclave economy debate. Sociology 35 (3): 671-693.

Wilson, Kenneth, and Alejandro Portes. 1980. Immigrants enclaves: An analysis of the labour market experiences of Cubans in Miami. American Journal of Sociology 86: 295-319.

Yuengert, Andrew. 1995. Testing hypothesis of immigrant self-employment. Journal of Human Resources 30 (1): 194-204.

Zhou, Min. 2004. Revisiting ethnic entrepreneurship: Convergencies, controversies and conceptual advancements. International Migration Review 38 (3): 1040-1074.

Submit your manuscript to a SpringerOpen ${ }^{\circ}$ journal and benefit from:

- Convenient online submission

- Rigorous peer review

- Open access: articles freely available online

- High visibility within the field

Retaining the copyright to your article 